\title{
NOMINATIVE EMOTIVE UNITS IN POETIC TEXT: A COGNITIVE STUDY
}

\author{
Inna Redka \\ Ph.D., Assistant Professor, Borys Grinchenko Kyiv University, Ukraine \\ e-mail: i.redka@kubg.edu.ua, orcid.org/0000-0002-3088-9651
}

\section{Summary}

The paper is focused on studying nominative emotive units in poetic texts, that are thought to carry the generalized information about the emotions and feelings of communicants and thus are devoid of any poetic potential. However, this paper undertakes an attempt to prove the opposite. The nominative emotive units are analyzed with regard to the methods of cognitive analysis. It has been stated that such linguistic units are based on emotional concepts that embrace affective and factual information pertaining to emotiogenic situations. It has been also stated that the emotional concept has scalar characteristics which are associated with the dynamic nature of feelings. The combination of nominative emotive units renders the ontological aspect of emotions. The stages of the emotive unit formation are modelled and outlined in the paper to show that communication of emotional imagery is possible through them. The paper also proves that nominative emotive units render the ontological aspect of feelings flow with a high degree of accuracy. At the same time they demonstrate a number of aesthetic features.

Keywords: emotiology, image of emotion, cognitive and affective structure, emotional concept.

DOI: https://doi.org/10.23856/4513

\section{Introduction}

Poetic texts have long been the point of interest among many scholars who worked (and are still working) within different paradigms of poetics and highlighted many aspects of such kind of text: structural (R. Jacobson, D. Magomedova), semantic (Yu.Tynyanov, A. Stepanov, O. Sedakova), pragmatic (M. Beloglazova, K. Kuliomina, M. Yegorov), semiotic (Yu Lotman) and cognitive (R. Tsur, M. Freeman, L. Byelyekhova, T. Gorchak, O. Marina). At the moment, new interdisciplinary studies are being initiated with the aim to explain the complex nature of such poetic constructs as verbal poetic images, the image of persona, etc. Today, the many linguists throughout the entire world (R. Tsur, M. Burke, N. Bolotnova, M. Nashkhoyeva, L. Byelyekhova) are focused on the issues of how the emotions of the addresser are fixed with linguistic means in poetic texts. Their research work in this direction has set up a new research field which is known as "emotiology".

Many points have been clarified about the linguistic representation of human emotions: 1) the structure of the emotional concept (Vezhbytskaya, 1996); 2) the structure of specific emotional concepts (Vorkachiev, 2012; Krasavsky, 2001; and other); 3) the role of metaphorical structures in conceptualizing the emotions (Lakoff \& Johnson, 1980); 4) the verbal representation of emotions in the emotive units (Shakhovsky, 2016; Nizhnik \& Galaidin, 2021); 5 ) the cultural aspects of rendering emotional images into the target language in the process of translation (Babelyuk, 2017; Gliebkin, 2010) However, the present-day findings do not give a comprehensible picture of the complex nature of lexical units that name emotions in poetic texts. The point seems to be interesting because nominative units naturally carry the 
generalized information about the referents, and this is not quite appropriate for poetic texts which offer unique viewpoints on mundane things. So, we will first try to get an insight into the conceptual ground of the nominative emotive units and then trace how the emotional concepts get organized and manifested in the nominative emotive units of the poetic texts to render the ontological features of feelings (the flow of emotions) of the addresser. The study is carried out on the basis of the poem "Cycle of my emotions" by Evy Moore (Moore) which abounds in nominative emotive units.

The current study is backed up with two statements. The first one being the quote by the famous American poet Robert Frost (1874 - 1963) who once explained the nature of poetry saying that "[it] is when an emotion has found its thought and the thought has found words". The second statement belongs to the contemporary scholar V. Gliebkin who commenting on the theory of emotional concepts by A. Wierzbicka stated that "there is next to no distance between the emotion itself and its representation in the language" (Glebkin, 2010).

This study, on the one hand, goes in line with the research methods pertaining to linguistics of emotion (V. Shakhovsky et al.), and on the other hand, it uses the methods of cognitive studies of linguistic units. In order to interpret the psychological aspects of emotions, we refer to psychological theories of human emotions (C. Izard).

\section{Emotional or emotive?}

We would like to start with the clarification of the terms that seem to be identical, and thus they are often misinterpreted and misused. They are the adjectives emotional and emotive. The first one derives from the noun "emotion" which is "a complex reaction pattern, involving experiential, behavioral, and physiological elements, by which an individual attempts to deal with a personally significant matter or event" (APA Dictionary of Psychology). If we refer to the etymology of the term emotion, we will clearly see that this notion is highly dynamic. The components of the word express movement from within, setting something or somebody to motion; stirring; agitating (< Middle French émotion < Old French emouvoir "stir up" > Latin emovere - moving out from; within the word the prefix ex-stood for "out, from" and the stem movere meant "moving" < PIE stem *meue-"pushing") (Online Etymology Dictionary). So, adding of prefix $e$ - to the word movere resulted in the meaning "moving out from". Thus, every emotion is associated with some kind of action.

The terms emotion and emotiveness are closely connected with each other as primary and secondary notions. The second term is coined specifically for linguistic purposes to differentiate the emotional state of a communicant from the verbal manifestation of such state (Shakhovsky, 2016). The adjective emotive is suggested and widely used by linguists to point out at the manifestation of emotions in texts. So, the emotive unit carries the information of the emotional state or feeling of the speaker. The adjective emotive gives rise to the noun emotiveness (or its less common lexical variant emotivity) - the term denoting the category of a fictional text which appears as the unity of form (stylistic means), the meaning (the emotional images that underlie them) and function which lies in rendering the author's emotions through such stylistic means.

The emotiveness is represented in the text by emotive units. Emotive units are the linguistic units of different language levels that carry fragments of emotional experience of the author. With regard to their size and amount of information that they carry, the emotive units can be of two types: 1) micro- and 2) macro- emotive units. The first group is represented by stylistic means of phonological, graphical, morphological, lexical or syntactical levels of 
the language; they are usually used to mark fragments of emotional experience of the author or nuances of their emotional states. According to their manner of manifestation in the text, microemotive units fall into explicit (units of nominative and descriptive character) and implicit (units of expressive character). A macroemotive unit is defined as an emergent implicit textual construct. It goes in line with the message of a poetic text. In its nature, macroemotive unit is the image of complex positive, negative, or ambivalent emotion; or a chain of emotive images that reflects the flow of emotions of a communicant.

A nominative emotive unit is a lexical unit that marks explicitly basic, commonly known emotional images. The words such as happiness, sadness, anger, etc. are the examples of nominative emotive units.

\section{Conceptual ground of nominative emotive units}

We will now try to reconstruct the conceptual ground of nominative emotive units. The conceptual analysis will help to outline the structure and content of the emotional concept. It will later give us a possibility to see which pieces of information are highlighted/hidden in nominative emotive units which create poetic qualities of a text.

Nominative emotive units appear as a result of affective and cognitive processes or mechanisms of the writer. The essence of this mechanism can be explained in the following way: every kind of stimulus triggers some sort of affective response in a person. Thus, the cognition goes hand in hand with emotionality of a person. Affective and cognitive mechanisms are inseparable from each other though they have different ontological properties (Piazhe, 1996; Izard, 2006; Damasio, 2005): the first are diffuse, and they either accompany the cognitive processes (whose essence lies in structuring the information that comes from the natural environment) or vice versa stimulate them.

The recurrence of life situations sets the links between the factual information and its emotional backing in the mind of a person. The fragments of information may then function as triggers of specific emotional responses. While reflecting on some life issues, the poet expresses his own attitude to them (Kukharenko, 2004). Thus, the fictional text appears as the product of selection of the fragment of real life and the reflection of the individual manner of its perception (Kukharenko, 2004). The selection is not haphazard, but is subdued to different mechanisms including emotions (Kukharenko, 2004) of the writer.

The regular perceptive and affective cooccurrences lead to the formation of the cognitive and affective structures (CAS) in the mind of the person. CAS is defined as a mental construal that carries the information about the emotional perception of some piece of information by a person.

CAS can be of different configurations. They may appear as a combination of 1) drive (a physical need) and a cognitive process; 2) emotion and a cognitive process; 3 ) the combination of the mentioned above patterns (Izard, 2006).

CAS can be simple and complex. The simple ones reflect the basic emotions of a person. The complex CAS can embrace the evaluative components, ideals, and human values. Thus, love, self-esteem, pride, dignity and courage are naturally regarded as human values that are based on emotions. The whole network of CAS can become the basis of the world view of a person or ideology of a group of people.

The author can be fully, partially, or absolutely unaware about the affective component of CAS. Therefore, it may stay in his subconscious sphere and get activated in a process of poetry writing. 
The most recurring and stable CAS that a person differentiates from other similar constructs become the units of thinking which are otherwise known as concepts. So, some concepts embrace both notional and emotiogenic sides. They appear to be not only as the units of thinking, but also as emotiogenic units or units that can trigger the emotions of the communicant (Vorkachev, 2012: 42, 43; Krasavsky, 2001: 29).

The emotional concept (it is called "emotional", but not "emotive" since it is devoid of the pragmatic potential which is always present within the emotive unit of a language) is the mental representation of the inner feeling in the verbal profile of a person (Kutuzova, 2015: 398]. Emotional concepts form the emotional map of an individual or a language community (Krasavsky, 2001: 29). Among the characteristic features of the emotional concepts, Shirokova distinguishes abstractness, volatility, and diffuseness. Emotional concepts relate to other concepts through the associative links (Shirokova, 2011).

The emotional concept has scalar characteristics. It means that emotion is usually conceptualized as a dynamic phenomenon which has 1) the starting point; 2) the uprising trajectory which leads to its 3) peak (the point of the highest intensity); 4) the down-falling trajectory (decrease of emotional tension) which leads to the 5) "affective zero" point. Fig. 1.

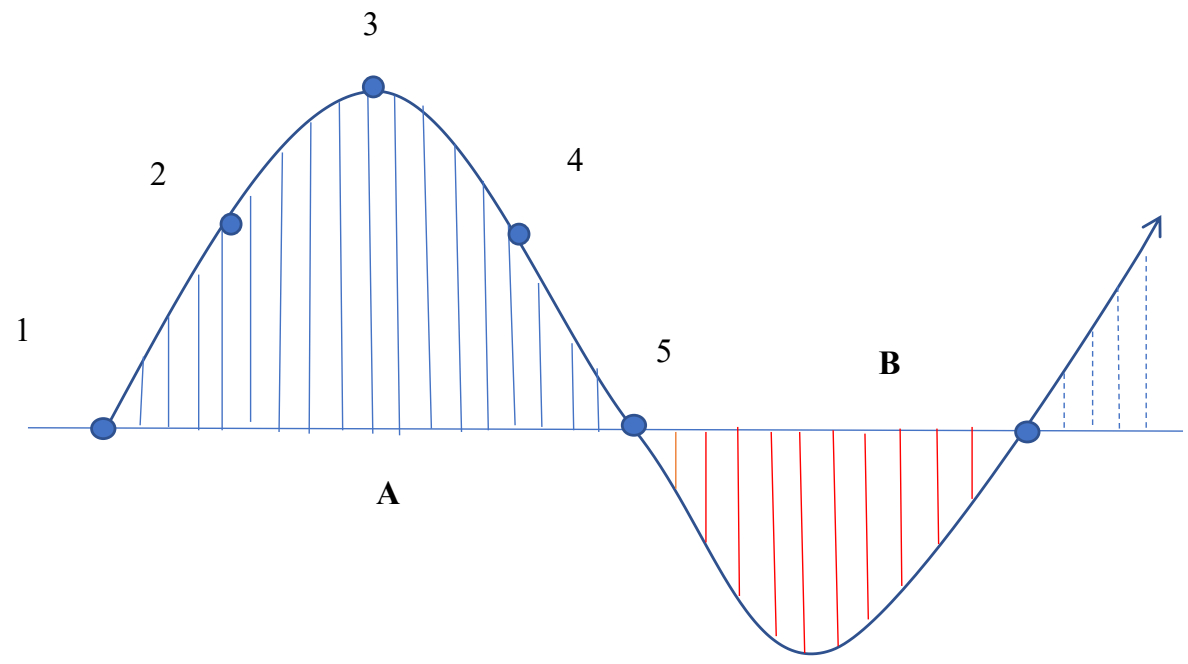

Fig. 1. Scalar features of emotional concept

If the movement of emotion through all stages of its development is over, the image of emotion can be superseded with its counterpart within the context of the literary work (Luk, 1982; Shirokova, 2015). The joining between the two emotional concepts occurs in either positive or negative directions depending on the chain of emotiogenic situations.

The other theory explains the emotional concept as a mental unit which contains the condensed representation of the emotional situation (Vezhbytskaya, 1996). The emotional concepts are language universals with the help of which it is possible to represent the basic emotions of a person explicitly (Vezhbytskaya, 1996: 326). A. Wierzbicka suggested the language models that represent the behavioral patterns and scenarios that underlie the feelings of a person(Vezhbytskaya, 1996: 326). 
The analysis of prototypical situations resulted in suggesting two prototypical models of emotions: 1) to feel sth as a result of some thoughts; and 2) to feel like sb who was thinking likewise (Vezhbytskaya, 1996: 337).

So, the emotional concept is a mental construal of the experienced emotion or feeling that contains condensed information about the emotion-inducing situation.

The stages of the formation of the emotive unit are shown on Fig. 2. The stimulus "S" evokes interoceptive feeling which may be of positive/negative valency and low/high intensity. The awareness about the feeling (including getting knowledge of the emotional situation, emotional triggers) stipulates the formation of CAS. The formation of awareness about the affective component of CAS results in the formation of the emotional concept. The verbalization of the emotional concepts leads to the formation of emotive units including the nominative ones.

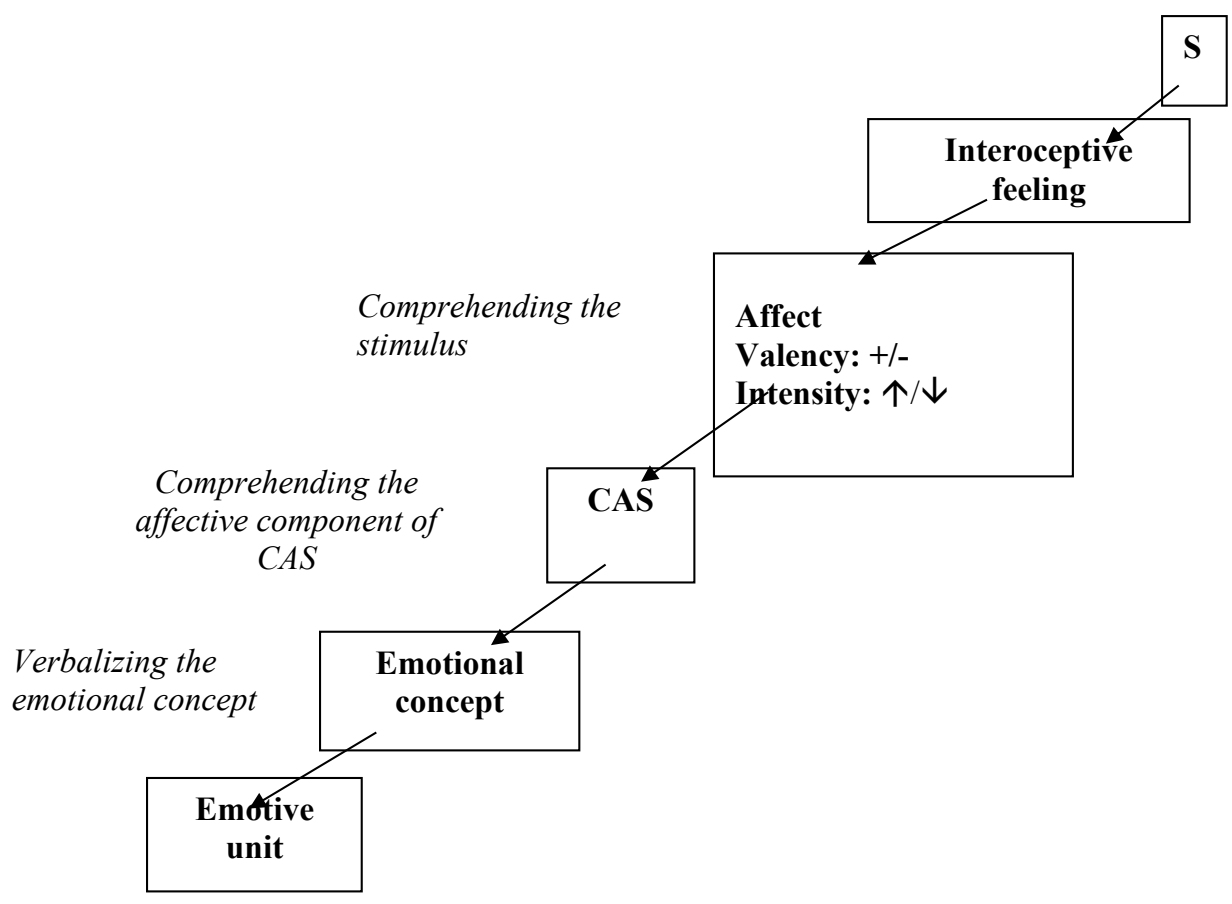

Fig. 2. Stages of emotive unit formation process

\section{Nominative emotive units and aesthetic writing}

Let us now consider how nominative emotive units function in the piece poetry written by Evy Moore (Moore). The analyzed text is notable for the high compression of verbal means. It means that its full sense can be grasped only through a thorough analysis of its conceptual structure. 


\section{Love leads to pain \\ Pain leads to hatred \\ Hatred leads to sorrow \\ Sorrow leads to despair \\ Despair leads to pleasure \\ Pleasure leads to happiness \\ Happiness leads to love \\ Love leads to pain}

The verbal design of the poem explicitly reveals the ontological characteristics of feelings of the addresser. Thus, we observe the ephemeral character of feelings of the persona. One feeling transforms into the other. Taking into account the fact that an emotion always pops up as a reaction to a certain stimulus, and that image of feelings are interoceptive constructs, in the context of this poem, the emotive units highlight the affective side of CAS, whereas the situational details that induce the mentioned feelings stay either hidden or implied. They can be interpreted only with regard to the typical situations that trigger similar feelings in a person who is faced with them.

On the verbal level of the poem, the emotive units are represented by the lexemes love pain - hatered - sorrow - despair - pleasure - happiness that mark basic feelings. Emotional concepts, activated by the emotive units contain the information about the CAS of the author (the valency and intensity of the affect, and peculiarities of the situation that caused such feelings) in the condensed form.

Thus, in the context of this poem, the image of feeling of love acquires a negative valency and at the same time high intensity. The agitation that is embodied in the external image of pain is marked verbally by the word pain.

The excess of the inner pain of the persona transforms into the feeling of hatred which supposedly appears due to the inability to approach the beloved person.

It is universally perceived that hatred is marked by the negative valency and high intensity, so exhausting character of this feeling usually makes a person get rid of it (through putting up with the situation that settles).

Thus, the decrease of the intensity of hatred transforms this feeling into the emotion of sorrow because of the lost love. Deepening affective characteristics of sorrow in the aspect of negative valency and low intensity results in the emergence of the interoceptive feeling of despair. The excess of despair leads to the exhaustion of this inner sensation, and this makes the emotional structures of the poem move in the opposite direction. Thus, the exhaustibility of the experienced feeling leads to relief - the feeling of pleasure - the affect with the positive valency of the low intensity. The rising of this affect results in the peak of this feeling - the emotion of happiness, which is associated with a presence of a particular person. So, the author returns to the image of love, the exhaustion of which again leads to inner pain.

The mercurial qualities of feelings are marked in the text by the cases of catch repetitions which on the textual level group to form the framing structure. Switching between the emotive units throughout the poetic text creates and getting back to the initial one results in creating cyclic qualities of emotiveness.

The micro emotive units are arranged into a macro emotive image - the constant flow of emotion of the persona.

The aesthetic qualities of this poem lie in its simplicity: the nominative emotive units that are rarely used in poems due to the fact that they are common words and thus devoid of 
expressive power are arranged skillfully in the text to show the chain of states the persona undergoes. The absence of details in the text as to emotiogenic situations may generate the multitude of interpretations.

\section{Conclusions}

The analysis proved the statement that there is a very little distance between the emotion and its verbalization in the poetic text. Nominative emotive units render the ontological capacities of feelings, on the one hand, and demonstrate the aesthetic features that render the beauty of the flow of emotions, on the other.

The empirical study is needed to back up the findings of the paper. It may also prove or disprove the universal features of the interpretation.

Further research is needed to study properties of descriptive and expressive emotive units in rendering ontological features of emotions.

\section{References}

1. APA dictionary of psychology. https://dictionary.apa.org/emotion.

2. Babelyuk, O. (1). CULTURE STRATEGY IN TRANSLATING POSTMODERN LITERARY TEXT. Scientific Journal of Polonia University, 22(3), 23-26. https://doi.org/10.23856/2202

3. Damasio A.R. (2005). Descartes'Error. Emotion, Reason, and the Human Brain // Antonio R. Damasio. - Penguin Books.

4. Glebkin V.V. (2010). Emotsii kak mezhdistsiplinarny fenomenon. Vestnik RTGGU. Seiya: Literaturovedeniye. Yazykoznaniye. Kulturologiya, (9 (52)). [in Russian]

5. Izard K.E. (2006) Psihologiya Emotsiy. St. Petersburg: Piter. [in Russian]

6. Krasavsky N.A. (2001). Emotsionalnyye kontsepty v nemetskoi i russkoi linguoculturah. Vogograd: Peremena. [in Russian]

7. Kukharenko V.A. (2004). Interpretatsiya tekstu. Vinnytsa: Nova Knyga. [in Ukrainian]

8. Kutuzova T.V. (2015). Emotsionalniye kontsepty $i$ sposoby ikh yazykovoi obyectivatsii. Movni I kontseptualni kartyny svitu. Kyiv: KNU im. Tarasa Shevchenka. № 1. [in Russian]

9. Lakoff G., Johnson M. (1980). Metaphors We Live By. Chicago: The University of Chicago Press. 10. Luk A.N. (1982). Emotsii i lichnost. Moskva: Znaniye. [in Russian]

11. Moore E. Cycle of my emotions. https://www.poemhunter.com/poem/cycle-of-my-emotions/. 12. Nizhnik, L., \& Galaidin, A. (2021). MODAL VERBS TO EXPRESS CONFIDENCE / UNCERTAINTY. Scientific Journal of Polonia University, 40(3), 49-59. https://doi.org/10.23856/4007. 13. Online Etymology Dictionary. https://www.etymonline.com/search? $q=$ emotion.

14. Piazhe Zh. (1996). Affektivnoye bessoznatelnoye i kolektivnoye bessoznatelnoye. Voprosy filosofii. № 6. [in Russian]

15. Shakhovsky V.I. (2016). Dissonans ecologichnosti v kommunikativnom kruge: cheloviek, yazyk, emotsii [Dissonance of ecology in communicative circle: man, language and emotions]. Volgograd. [in Russian]

16. Shirokova I.A. (2011). Osobennosti struktury emotsionalnogo kontsepta i ego izucheniye $v$ aspecte perevoda. Aktualniye voprosy filologicheskikh nauk: problemy i perspectivy. Chita: Molodoi ucheniy. [in Russian]

17. Vezhbytskaya A. (1996). Yazyk. Cultura. Poznaniye. Moscow: Russkiye slovari. [in Russian] 18. Vorkachev S.G. (2012). Anglica selecta: izbrannyye raboty po linguokontseptologii. Volgograd: Paradigma. [in Russian] 